\title{
Assessment of soil quality in the area of casting parts waste storage specific to cast iron activities
}

\author{
BOGDAN ADRIAN STANESCU*, ADRIANA CUCIUREANU
}

National Research and Development Institute for Industrial Ecology - ECOIND, 57-73 Drumul Podul Dambovitei Street, 060652, Bucharest, Romania

*Corresponding author: stanescubogdan2@gmail.com

$\begin{array}{lll}\text { Received: } & \text { Accepted: } & \text { Published: } \\ \text { 23.05.2021 } & 25.06 .2021 & 25.06 .2021\end{array}$

\begin{abstract}
The purpose of this paper was to present an environmental assessment specific to a case study with reference to the storage of sand waste from a cast iron foundry, a factory with a long period of operation located in Transylvania, Romania. The environmental assessment started from the need to achieve compliant conditions for long-term storage of waste specific to cast iron casting parts activities. The activities performed in the project were carried out in stages and in parallel with the activities of sand waste valorification from the non-compliant deposit. The collaboration of the factory owner with the local environmental authorities was able to effectively materialize the objectives of the soil evaluation and facilitated the obtaining conditions for new compliant deposit construction. The evaluation of the soil quality was performed in areas where the deposited material, respectively the sand waste from the casting of the cast iron was already valorificated and, in that case, the access to the soil layer was facilitated. Thirty soil samples and a control sample were analyzed and interpretation of the results was performed in corelation to specific legislation. The conclusions of the study were provided to the beneficiary and, also to the environmental authorities in order to authorize future activities (capitalization of the remaining waste, arrangement of a new landfill).
\end{abstract}

Keywords: cast iron, sand waste, soil, assessment

\section{INTRODUCTION}

It is known that the cast iron processing industry for obtaining cast iron parts generates significant amounts of waste, due to the specifics of this casting activity in sand molds [1].

After the castings parts are obtained, the mold used and the sand used in it become a secondary products. There are mentioned uses of sand that has become waste as being used in the building materials industry [2].

Numerous researches have been carried out on the composition of residual sand. The results of the experiments showed that the residual foundry sand is a new material, with a modified composition, compared to fresh sand [3-11].

Most foundry sands are non-hazardous waste, but environmental authorities are often reluctant to allow their beneficial use in agricultural and geotechnical applications due to metal leaching concerns. Different models of leaching metals from soil to groundwater have been applied, in different climatic conditions, and the conclusions have highlighted a potential for groundwater pollution, only in areas with a humid climate where the water ratio is excessive. [12].

At this time, only sand waste from ferrous castings is considered to be environmentally acceptable. Through laboratory analyzes, the mechanical and physical properties were studied and a series of utilisations in civil engineering were identified: filling material for embankment, replacement of fine aggregate in asphalt or use in concrete [13]. 
There are notable results regarding the waste sand in geopolymer materials. The physical and mechanical characteristics of this materials were determined and the conclusions resulting from the experiments led to uses in light construction materials, and certain experimental variants revealed a good behavior for use in making the walls [14]. Other research has been directed to use in the manufacture of the controlled construction materials with low strength and as a concrete additive. The implications on the properties of concrete, such as compressive strength, tensile strength, modulus of elasticity, frost-thaw resistance and thermal shrinkage, have been studied [15].

In many cases, sand waste from foundries is depositated outside the foundry, where storage space is limited. Therefore, stored sand waste can exceed the volume of on-site storage facilities, creating an obstacle to production. Moreover, there are concerns about the impact on the environment, where the leaching of contaminants to the groundwater is posible [16].

A number of studies have focused on ways to remove pollutants from foundry sand by chemical washing. The problem is that the pollutant removal efficiencies are quite variable, but for important pollutants such as $\mathrm{Pb}$, As and $\mathrm{Zn}$, it is notable that the removal was achieved in proportion of $100 \%$ [17].

The disposal of the industrial wastes creates significant hazards to the environment and health. The presence of industrial wastes at a site involves the assessment of the soil quality, including site history, in order to identify which categories of pollutants need to be analyzed. In many situations, it is necessary to assess the ecological and health risk to sensitive receptors in the area if the storage is close [18].

Regardless the age of the landfills, in order to be assessed in terms of establishing the quality of environmental components, soil investigations is necessary, as a premise for elucidating the extent to which the landfill releases pollutants into environment. During the last decade, experimental research has been conducted that has highlighted the impact of non-compliant landfills on environmental components. The impact of these deposits should not be neglected taking into account the fact that these deposits are located in the vicinity of inhabited areas in the urban environment [19].

In the most common meanings, pollution is defined as a major, undesirable change in the physical, chemical and biological properties of the environmental factors, that affect human life, plants and animals, industry, in terms of its development and progress, cultural values and living conditions [20].

The aim of the study was to investigate the soil quality in landfill area of iron-cast sand wastes in order to assess and support the decision of environmental local authorities to permitted a construction of a new landfill in those area.

\section{EXPERIMENTAL PART}

The context of the report regarding the investigation and assessment of the soil quality for a cast iron factory - foundry pieces, located in the central part of Romania, in Transylvania is related to the requests of the public environmental protection authority to a multi staged rehabilitation project regarding the deposit of sand foundry waste in the vicinity of the factory, to be approved for implementation.

Figure 1 presents the location of the site reported to Alba Iulia City limits. 


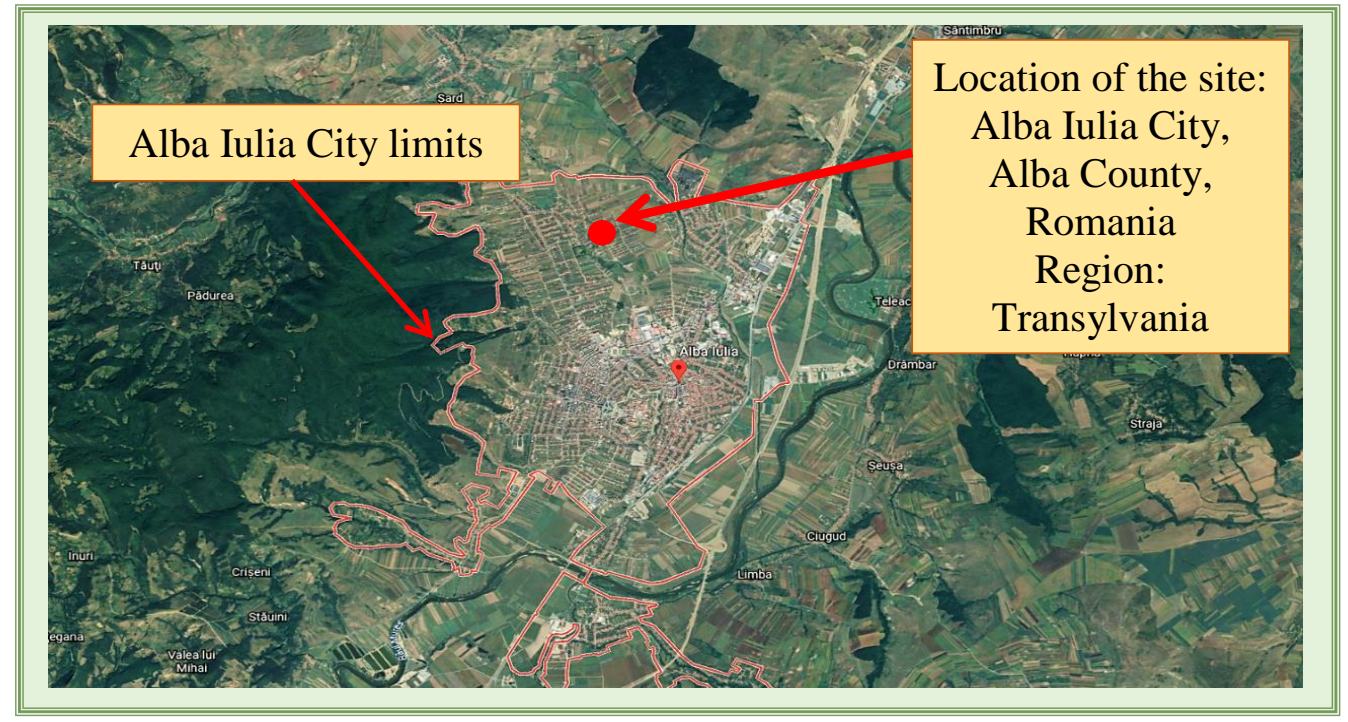

Fig. 1. Location of the site in the northern part of the Alba Iulia City

The elements of the conceptual framework for conducting the soil investigations are presented in figure 2.

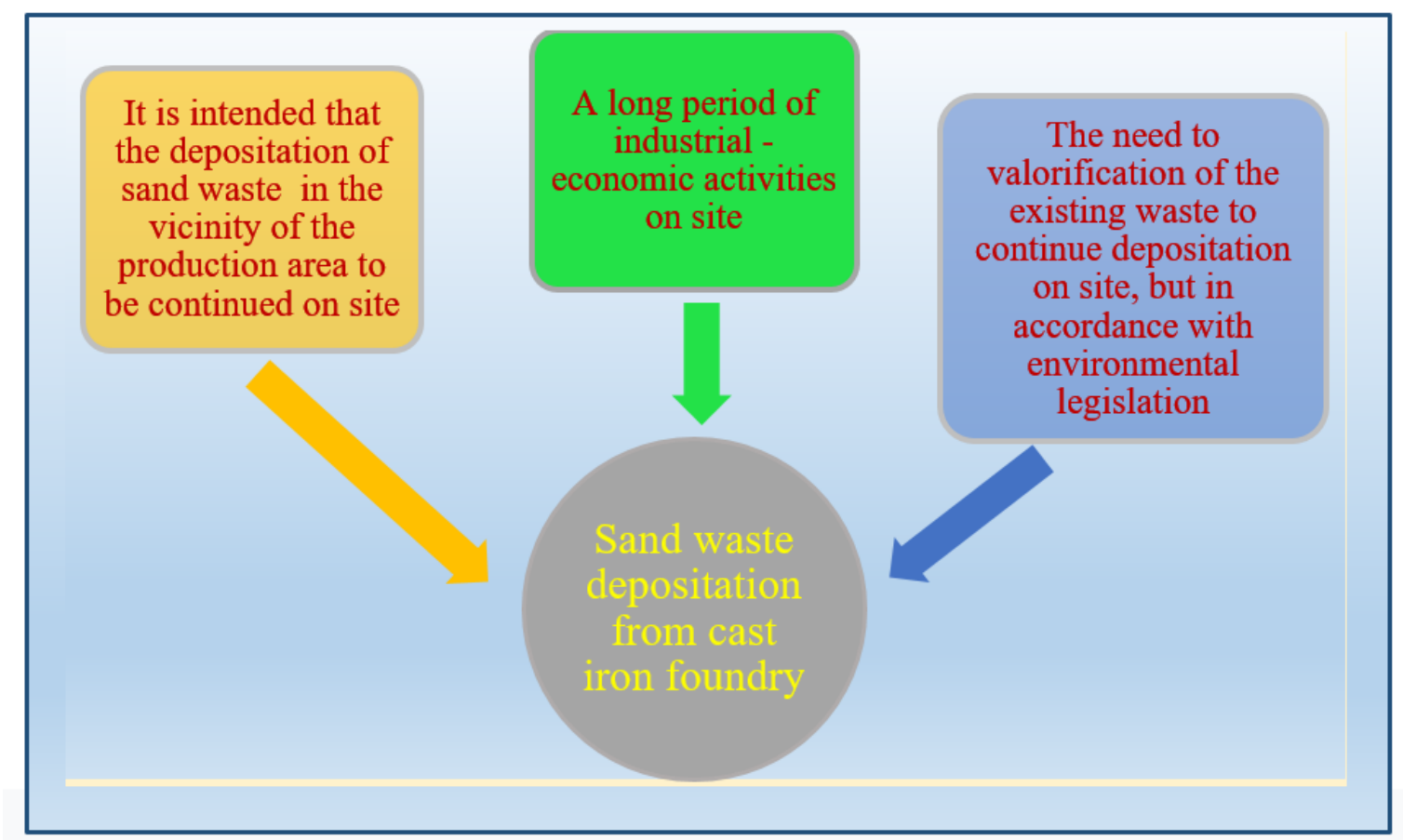

Fig. 2. Conceptual model - base elements for conducting the soil investigations

Therefore, in the present study, the activities carried out had as objective the highlighting the soil quality in the area (10600 sqm) released from waste, due to the takeover and valorification procedures of the waste by a proximity cement factory.

The field visit highlighted a number of details. First of all, it was noticed that some terrain surfaces had waste sand, a machine for sieving the waste and a platform for loading it in trucks being operated. In agreement with the factory representatives, a solution was founded to ensure access to the soil layer in order to collect soil samples.

The samples were collected from 15 points, and an Edelman-type pedological drill kit was used for sampling. The geographical coordinates of the sampling points were performed with Garmin GPS, model type Montana 610, being presented in Table 1. From each soil sampling point, two different 
soil samples were collected from the $0-10 \mathrm{~cm}$ and $40-50 \mathrm{~cm}$ depths, thus resulting a total of 30 soil samples. Additionally, a blank/reference soil sample was collected from $300 \mathrm{~m}$ distance from the waste storage area.

Table 1. Sampling points coordinates, GPS Garmin, model Montana 610

\begin{tabular}{|c|c|c|c|c|c|}
\hline Soil sample ID & Latitute & Longitude & Soil sample ID & Latitute & Longitude \\
\hline S1 & $46^{\circ} 6{ }^{\prime} 30.70^{\prime \prime} \mathrm{N}$ & $23^{\circ} 34^{\prime} 40.89^{\prime \prime} \mathrm{E}$ & S9 & $46^{\circ} 6^{\prime} 33.16^{\prime \prime} \mathrm{N}$ & $23^{\circ} 34^{\prime} 41.01^{\prime \prime} \mathrm{E}$ \\
\hline S2 & $46^{\circ} 6^{\prime} 31.10^{\prime \prime} \mathrm{N}$ & $23^{\circ} 34^{\prime} 41.52^{\prime \prime} \mathrm{E}$ & S10 & $46^{\circ} 6^{\prime} 33.51^{\prime \prime N}$ & $23^{\circ} 34^{\prime} 40.72^{\prime \prime} \mathrm{E}$ \\
\hline S3 & $46^{\circ} 6^{\prime} 31.95^{\prime \prime} \mathrm{N}$ & $23^{\circ} 34^{\prime} 41.46^{\prime \prime} \mathrm{E}$ & S11 & $46^{\circ} 6^{\prime} 33.70^{\prime \prime} \mathrm{N}$ & $23^{\circ} 34^{\prime} 40.02^{\prime \prime} \mathrm{E}$ \\
\hline S4 & $46^{\circ} 6^{\prime} 31.81^{\prime \prime} \mathrm{N}$ & $23^{\circ} 34^{\prime} 42.46^{\prime \prime} \mathrm{E}$ & S12 & $46^{\circ} 6^{\prime} 34.59^{\prime \prime} \mathrm{N}$ & $23^{\circ} 34^{\prime} 40.02^{\prime \prime} \mathrm{E}$ \\
\hline S5 & $46^{\circ} 66^{\prime} 32.01 " \mathrm{~N}$ & $23^{\circ} 34^{\prime} 42.03^{\prime \prime} \mathrm{E}$ & S13 & $46^{\circ} 6^{\prime} 34.74^{\prime \prime} \mathrm{N}$ & $23^{\circ} 34^{\prime} 40.90^{\prime \prime} \mathrm{E}$ \\
\hline S6 & $46^{\circ} 6^{\prime} 32.34^{\prime \prime} \mathrm{N}$ & $23^{\circ} 34^{\prime} 41.67^{\prime \prime} \mathrm{E}$ & S14 & $46^{\circ} 6^{\prime} 34.43^{\prime \prime} \mathrm{N}$ & $23^{\circ} 34^{\prime} 41.26^{\prime \prime} \mathrm{E}$ \\
\hline S7 & $46^{\circ} 6{ }^{\prime} 32.61 " \mathrm{~N}$ & $23^{\circ} 34^{\prime} 41.41^{\prime \prime} \mathrm{E}$ & S15 & $46^{\circ} 6^{\prime} 34.21^{\prime \prime} \mathrm{N}$ & $23^{\circ} 34^{\prime} 41.60^{\prime \prime} \mathrm{E}$ \\
\hline S8 & $46^{\circ} 6^{\prime} 32.91 " \mathrm{~N}$ & $23^{\circ} 34^{\prime} 41.21^{\prime \prime} \mathrm{E}$ & $\begin{array}{c}\text { Blank (reference } \\
\text { soil sample) }\end{array}$ & $46^{\circ} 6^{\prime} 29.02^{\prime \prime} \mathrm{N}$ & $23^{\circ} 35^{\prime} 8.89^{\prime \prime} \mathrm{E}$ \\
\hline
\end{tabular}

The location of the soil sampling points is shown in Figure 3.

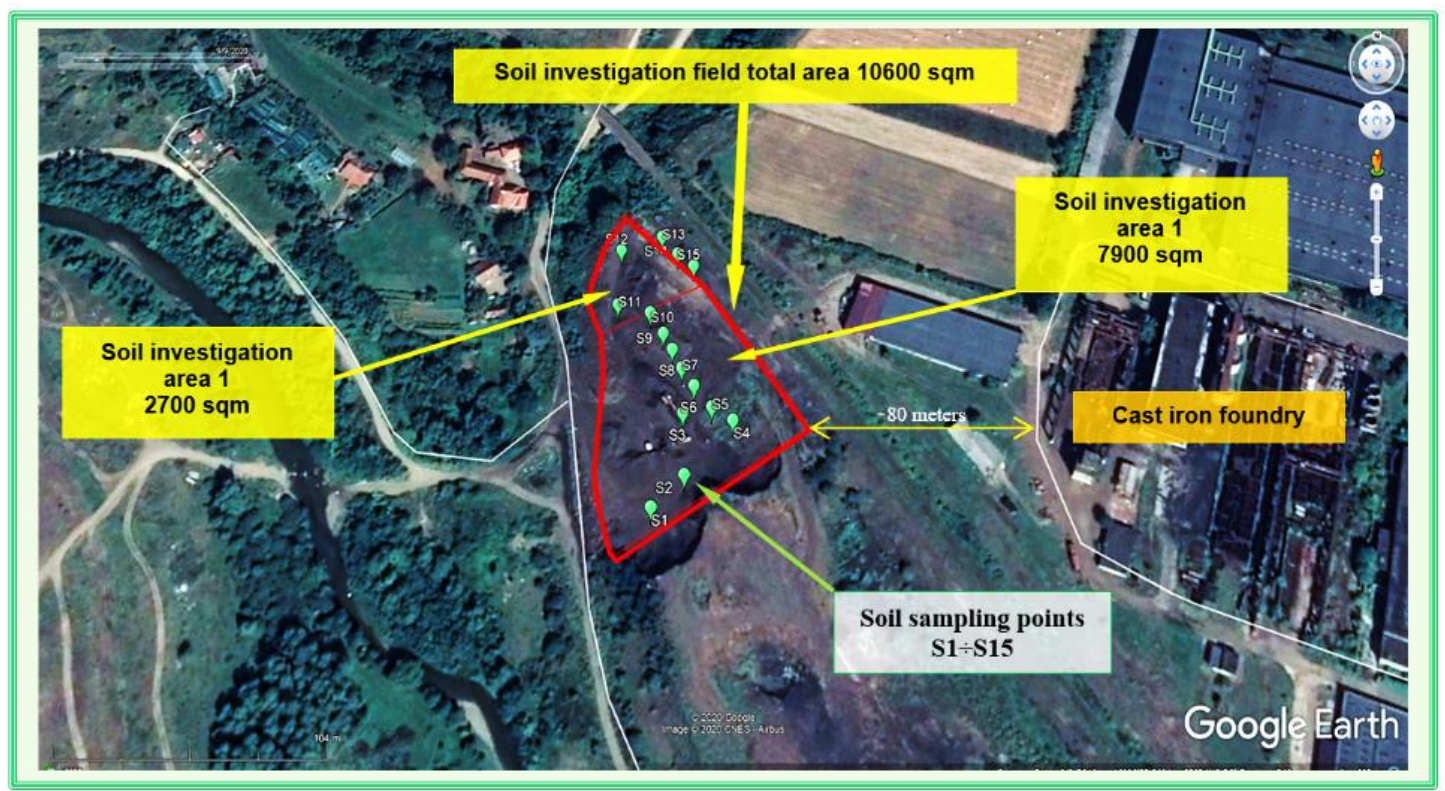

Fig. 3. Location of soil sampling points (source of map: Google Earth Pro 2020)

\section{RESULTS AND DISCUSSIONS}

For each soil sample, the quality indicators were analyzed and the standardized test methods were applied (table 2).

Table 2. Quality indicators and standardized test methods

\begin{tabular}{l|l}
\hline Parameter & Standard method \\
\hline pH & SR EN 15933:2013 \\
Moisture & SR EN 15934:2013 \\
Sulphides and hydrogen sulphide & SR ISO 10530:1997 \\
Sulphates & SR ISO 11048:1999 \\
THP & EPA 8440:1996 \\
Total iron & \\
Zinc & \\
Nickel & SR EN 16170:2017 \\
Manganese & SR EN 16174:2013 \\
Copper & \\
Lead & \\
\hline
\end{tabular}


Obtained analytical results for 30 soil samples and blank soil are presented in the tables $3 \div 7$.

Table 3. Analytical results for soil samples $\mathrm{S} 1 \div \mathrm{S} 3,0-10 \mathrm{~cm}$ and $40-50 \mathrm{~cm}$ depths

\begin{tabular}{|c|c|c|c|c|c|c|}
\hline $\begin{array}{l}\text { Quality indicator / } \\
\text { (measure unit) }\end{array}$ & $\begin{array}{c}\mathrm{S} 1 \\
0-10 \mathrm{~cm}\end{array}$ & $\begin{array}{c}\mathrm{S} 1 \\
40-50 \mathrm{~cm}\end{array}$ & $\begin{array}{c}\mathrm{S} 2 \\
0-10 \mathrm{~cm}\end{array}$ & $\begin{array}{c}\mathrm{S} 2 \\
40-50 \mathrm{~cm}\end{array}$ & $\begin{array}{c}\mathrm{S} 3 \\
0-10 \mathrm{~cm}\end{array}$ & $\begin{array}{c}\mathrm{S} 3 \\
40-50 \mathrm{~cm}\end{array}$ \\
\hline $\mathrm{pH}(p H$ units $)$ & 7.0 & 8.7 & 8.4 & 8.4 & 8.2 & 8.4 \\
\hline Moisture, $\%$ & 15.29 & 15.40 & 15.10 & 15.54 & 15.37 & 16.55 \\
\hline $\begin{array}{l}\text { Sulphides and } \mathrm{H}_{2} \mathrm{~S} \text {, } \\
m g / k g ~ d . m .\end{array}$ & $<1 *$ & $<1$ & $<1$ & $<1$ & $<1$ & $<1$ \\
\hline Sulphates, $m g / k g$ d.m. & 180 & 134 & 153 & 61.0 & 92.4 & 109 \\
\hline Total Iron, $m g / k g ~ d . m$. & 13650 & 19252 & 23956 & 25898 & 9698 & 18760 \\
\hline Zinc, $m g / k g$ d.m. & 22.8 & 27.8 & 40.5 & 40.3 & 17.4 & 38.2 \\
\hline Nickel, $m g / k g$ d.m. & 21.3 & 24.2 & 27.0 & 26.3 & 12.9 & 30.9 \\
\hline Manganese, $m g / k g ~ d . m$. & 329 & 619 & 300 & 384 & 321 & 675 \\
\hline Copper, $m g / k g ~ d . m$. & 18.4 & 21.0 & 26.2 & 25.2 & 10.1 & 20.0 \\
\hline Lead, $m g / k g ~ d . m$. & 9.92 & 9.66 & 9.42 & 8.03 & 4.42 & 13.8 \\
\hline THP, $m g / k g d . m$. & $<25^{*}$ & - & - & - & $<25$ & - \\
\hline
\end{tabular}

*detection limit of the method

It is important to mention that only for a selection of soil samples, the THP quality indicator was determined, only due to the fact that in those areas, used sand transport vehicles transited. In some areas, an excavator was used to remove material from the waste disposal, thus facilitating access to the underlying soil layer.

Table 4. Analytical results for soil samples $\mathrm{S} 4 \div \mathrm{S} 6,0-10 \mathrm{~cm}$ and $40-50 \mathrm{~cm}$ depths

\begin{tabular}{|c|c|c|c|c|c|c|}
\hline $\begin{array}{l}\text { Quality indicator / } \\
\text { (measure unit) }\end{array}$ & $\begin{array}{c}\mathrm{S} 4 \\
0-10 \mathrm{~cm} \\
\end{array}$ & $\begin{array}{c}\mathrm{S} 4 \\
40-50 \mathrm{~cm} \\
\end{array}$ & $\begin{array}{c}\mathrm{S} 5 \\
0-10 \mathrm{~cm} \\
\end{array}$ & $\begin{array}{c}\text { S5 } \\
40-50 \mathrm{~cm} \\
\end{array}$ & $\begin{array}{c}\mathrm{S} 6 \\
0-10 \mathrm{~cm} \\
\end{array}$ & $\begin{array}{c}\mathrm{S} 6 \\
40-50 \mathrm{~cm} \\
\end{array}$ \\
\hline $\mathrm{pH}$ (pH units) & 7.2 & 8.5 & 8.2 & 7.8 & 8.5 & 8.7 \\
\hline Moisture, \% & 10.93 & 12.60 & 11.72 & 12.80 & 14.20 & 13.40 \\
\hline $\begin{array}{l}\text { Sulphides and } \mathrm{H}_{2} \mathrm{~S} \text {, } \\
m g / k g \text { d.m. }\end{array}$ & $<1 *$ & $<1$ & $<1$ & $<1$ & $<1$ & $<1$ \\
\hline Sulphates, $m g / k g$ d.m. & 104 & 101 & 84.0 & 109 & 278 & 143 \\
\hline Total Iron, $m g / k g ~ d . m$. & 2777 & 2827 & 4988 & 1588 & 7445 & 1762 \\
\hline Zinc, $m g / k g$ d.m. & 8.18 & 5.32 & 13.8 & 3.10 & 10.8 & 3.91 \\
\hline Nickel, $m g / k g ~ d . m$. & 6.51 & 5.17 & 13.2 & 2.83 & 7.51 & 3.11 \\
\hline Manganese, $m g / k g ~ d . m$. & 28.8 & 32.5 & 52.6 & 15.7 & 80.6 & 115 \\
\hline Copper, $m g / k g ~ d . m$. & 2.44 & 3.21 & 6.15 & 2.87 & 7.11 & 3.04 \\
\hline Lead, $m g / k g ~ d . m$. & $<1.5^{*}$ & 8.96 & 2.38 & 2.36 & 2.40 & $<1.5$ \\
\hline
\end{tabular}

$*$ detection limit of the method

Table 5. Analytical results for soil samples $\mathrm{S} 7 \div \mathrm{S} 9,0-10 \mathrm{~cm}$ and $40-50 \mathrm{~cm}$ depths

\begin{tabular}{|c|c|c|c|c|c|c|}
\hline $\begin{array}{l}\text { Quality indicator / } \\
\text { (measure unit) }\end{array}$ & $\begin{array}{c}\mathrm{S} 7 \\
0-10 \mathrm{~cm} \\
\end{array}$ & $\begin{array}{c}\mathrm{S} 7 \\
40-50 \mathrm{~cm} \\
\end{array}$ & $\begin{array}{c}\text { S8 } \\
0-10 \mathrm{~cm} \\
\end{array}$ & $\begin{array}{c}\mathrm{S} 8 \\
40-50 \mathrm{~cm} \\
\end{array}$ & $\begin{array}{c}\text { S9 } \\
0-10 \mathrm{~cm} \\
\end{array}$ & $\begin{array}{c}\mathrm{S} 9 \\
40-50 \mathrm{~cm} \\
\end{array}$ \\
\hline $\mathrm{pH}$ (pH units) & 7.9 & 7.9 & 8.0 & 8.0 & 7.8 & 7.9 \\
\hline Moisture, \% & 3.91 & 4.20 & 6.10 & 3.96 & 4.40 & 4.01 \\
\hline $\begin{array}{l}\text { Sulphides and } \mathrm{H}_{2} \mathrm{~S} \text {, } \\
m g / k g \text { d. } m \text {. }\end{array}$ & $<1 *$ & $<1$ & $<1$ & $<1$ & $<1$ & $<1$ \\
\hline Sulphates, $m g / k g$ d.m. & 88.0 & 75.2 & 140 & 150 & 215 & 144 \\
\hline 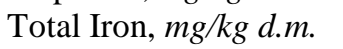 & 19332 & 24095 & 9052 & 17154 & 8419 & 22889 \\
\hline Zinc, $m g / k g$ d.m. & 20.4 & 30.8 & 16.9 & 28.5 & 13.0 & 27.2 \\
\hline Nickel, $m g / k g$ d.m. & 19.2 & 24.9 & 14.5 & 23.0 & 9.82 & 22.3 \\
\hline Manganese, $m g / k g ~ d . m$. & 294 & 287 & 223 & 554 & 262 & 430 \\
\hline Copper, $m g / k g ~ d . m$. & 15.9 & 18.1 & 11.2 & 18.7 & 6.95 & 15.7 \\
\hline Lead, $m g / k g$ d.m. & 8.04 & 7.77 & 7.54 & 11.8 & 2.90 & 7.39 \\
\hline THP, $m g / k g d . m$. & $<25 *$ & - & - & - & $<25$ & - \\
\hline
\end{tabular}

$*$ detection limit of the method 
Table 6. Analytical results for soil samples $\mathrm{S} 10 \div \mathrm{S} 12,0-10 \mathrm{~cm}$ and $40-50 \mathrm{~cm}$ depths

\begin{tabular}{|c|c|c|c|c|c|c|}
\hline $\begin{array}{l}\text { Quality indicator / } \\
\text { (measure unit) }\end{array}$ & $\begin{array}{c}\mathrm{S} 10 \\
0-10 \mathrm{~cm}\end{array}$ & $\begin{array}{c}\mathrm{S} 10 \\
40-50 \mathrm{~cm}\end{array}$ & $\begin{array}{c}\mathrm{S} 11 \\
0-10 \mathrm{~cm}\end{array}$ & $\begin{array}{c}\mathrm{S} 11 \\
40-50 \mathrm{~cm}\end{array}$ & $\begin{array}{c}\mathrm{S} 12 \\
0-10 \mathrm{~cm}\end{array}$ & $\begin{array}{c}\mathrm{S} 12 \\
40-50 \mathrm{~cm}\end{array}$ \\
\hline $\mathrm{pH}$ (pH units) & 8.3 & 8.0 & 7.7 & 7.6 & 7.9 & 7.9 \\
\hline Moisture, \% & 4.30 & 4.55 & 4.10 & 4.70 & 4.20 & 4.80 \\
\hline $\begin{array}{l}\text { Sulphides and } \mathrm{H}_{2} \mathrm{~S} \text {, } \\
m g / k g \text { d.m. }\end{array}$ & $<1^{*}$ & $<1$ & $<1$ & $<1$ & $<1$ & $<1$ \\
\hline Sulphates, $m g / k g$ d.m. & 730 & 168 & 116 & 108 & 107 & 65.0 \\
\hline Total Iron, $m g / k g$ d.m. & 22586 & 26264 & 20519 & 24543 & 17906 & 23864 \\
\hline Zinc, $m g / k g$ d.m. & 29.2 & 34.4 & 24.6 & 32.1 & 26.9 & 20.7 \\
\hline Nickel, $m g / k g$ d.m. & 23.4 & 23.7 & 20.0 & 26.2 & 24.2 & 23.2 \\
\hline Manganese, $m g / k g ~ d . m$. & 593 & 344 & 372 & 507 & 390 & 475 \\
\hline Copper, $m g / k g$ d.m. & 16.8 & 18.9 & 20.7 & 21.2 & 18.4 & 17.5 \\
\hline Lead, $m g / k g$ d.m. & 7.84 & 10.5 & 8.26 & 8.15 & 6.97 & 8.70 \\
\hline 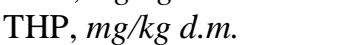 & - & 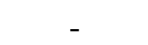 & $<25^{*}$ & - & - & 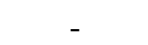 \\
\hline
\end{tabular}

*detection limit of the method

The interpretation of the results of the laboratory tests performed for 30 soil samples taken from the investigated site where used sand waste was deposited, was made in comparision with the reference values stipulated by Romanian Order $756 / 1997$ for approval Regulations on environmental pollution assessment with subsequent amendments and completions, respectively to the reference values for traces of chemical elements in the soil for "less sensitive land use", these includes all existing industrial and commercial uses, as well as land areas provided for such future uses [21].

Table 7. Analytical results for soil samples $\mathrm{S} 13 \div \mathrm{S} 15,0-10 \mathrm{~cm}$ and $40-50 \mathrm{~cm}$ depths and reference

\begin{tabular}{|c|c|c|c|c|c|c|c|}
\hline \multicolumn{8}{|c|}{ sample } \\
\hline $\begin{array}{l}\text { Quality indicator / } \\
\text { (measure unit) }\end{array}$ & $\begin{array}{c}\mathrm{S} 13 \\
0-10 \mathrm{~cm}\end{array}$ & $\begin{array}{c}\mathrm{S} 13 \\
40-50 \mathrm{~cm}\end{array}$ & $\begin{array}{c}\mathrm{S} 14 \\
0-10 \mathrm{~cm}\end{array}$ & $\begin{array}{c}\mathrm{S} 14 \\
40-50 \mathrm{~cm}\end{array}$ & $\begin{array}{c}\mathrm{S} 15 \\
0-10 \mathrm{~cm}\end{array}$ & $\begin{array}{c}\mathrm{S} 15 \\
40-50 \mathrm{~cm}\end{array}$ & $\begin{array}{l}\text { Reference } \\
\text { soil sample }\end{array}$ \\
\hline $\mathrm{pH}(p H$ units $)$ & 7.8 & 8.0 & 7.8 & 7.2 & 7.4 & 7.3 & 7.7 \\
\hline Moisture, \% & 4.53 & 4.30 & 4.52 & 4.110 & 18.94 & 14.55 & 13.04 \\
\hline $\begin{array}{l}\text { Sulphides and } \mathrm{H}_{2} \mathrm{~S} \text {, } \\
m g / k g \text { d.m. }\end{array}$ & $<1 *$ & $<1$ & $<1$ & $<1$ & $<1$ & $<1$ & $<1$ \\
\hline Sulphates, $m g / k g$ d.m. & 80.0 & 114 & 88.4 & 71.9 & 112 & 111 & 116 \\
\hline Total Iron, $m g / k g ~ d . m$. & 22982 & 17136 & 14964 & 9057 & 20491 & 19138 & 22844 \\
\hline Zinc, $m g / k g ~ d . m$. & 27.7 & 28.2 & 20.2 & 13.9 & 31.6 & 27.7 & 50.6 \\
\hline Nickel, $m g / k g$ d.m. & 23.9 & 24.7 & 19.6 & 16.2 & 25.0 & 24.4 & 25.4 \\
\hline Manganese, $m g / k g ~ d . m$. & 593 & 517 & 585 & 433 & 644 & 575 & 832 \\
\hline Copper, $m g / k g ~ d . m$. & 15.6 & 16.1 & 14.1 & 12.8 & 17.7 & 16.3 & 30.2 \\
\hline Lead, $m g / k g ~ d . m$. & 7.64 & 7.54 & 5.85 & 6.81 & 7.97 & 7.54 & 29.8 \\
\hline $\mathrm{THP}, m g / k g$ d.m. & - & - & - & - & $<25^{*}$ & - & - \\
\hline
\end{tabular}

*detection limit of the method

The using less sensitive of land, includes all existing industrial and commercial use, as well as land areas that required such uses future.

The reference values and the alert and intervention thresholds corresponding to the less sensitive use category are presented in Table 8 .

Table 8. Reference values for less sensitive land use [21]

\begin{tabular}{c|cccc}
\hline Quality indicator & Measure unit & Normal values & Alert Threshold & Intervention Threshold \\
\hline Sulphates & mg/kg d.m. & - & 5000 & 50000 \\
Sulphides & mg/kg d.m. & - & 400 & 2000 \\
$\mathrm{Zn}$ & mg/kg d.m. & 100 & 700 & 1500 \\
$\mathrm{Ni}$ & mg/kg d.m. & 20 & 200 & 500 \\
$\mathrm{Mn}$ & mg/kg d.m. & 900 & 2000 & 4000 \\
$\mathrm{Cu}$ & mg/kg d.m. & 20 & 250 & 500 \\
$\mathrm{~Pb}$ & mg/kg d.m. & 20 & 250 & 1000 \\
$\mathrm{THP}$ & mg/kg d.m. & $<100$ & 1000 & 2000 \\
\hline
\end{tabular}


The variations of the values recorded for heavy metals in the soil are graphically presented in figures $4 \div 8$. The graphs present also the "normal values" that was established for each parameter [21].

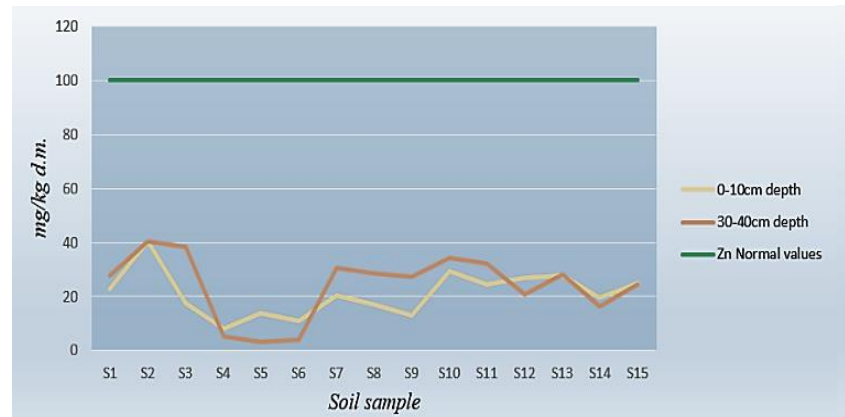

Fig. 4. Variations of $Z n$ in soil samples

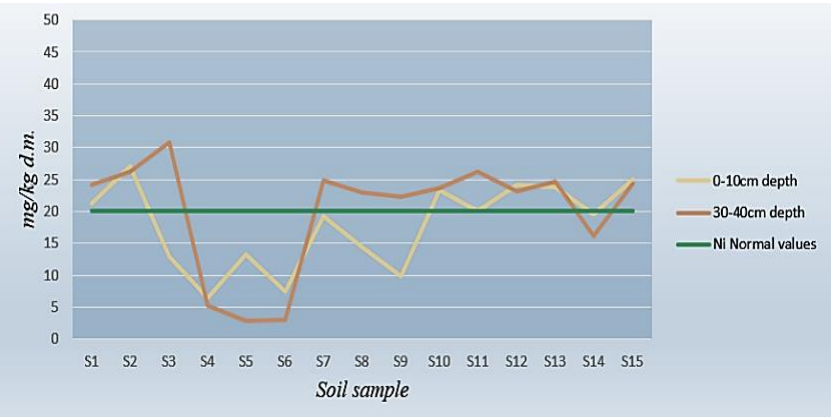

Fig. 5. Variations of $\mathrm{Ni}$ in soil samples

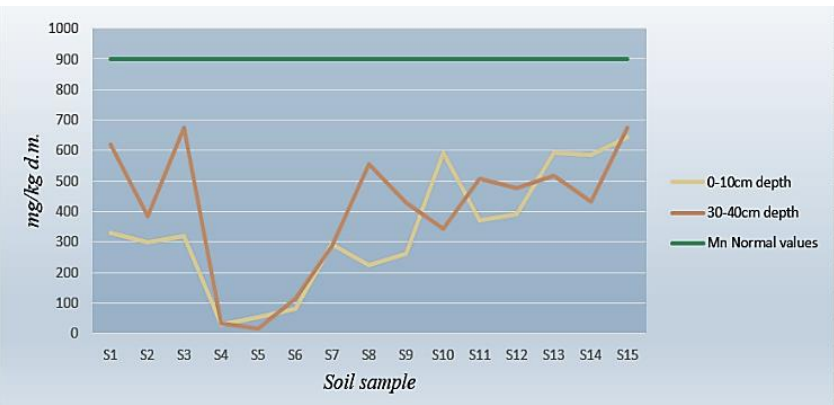

Fig. 6. Variations of $M n$ in soil samples

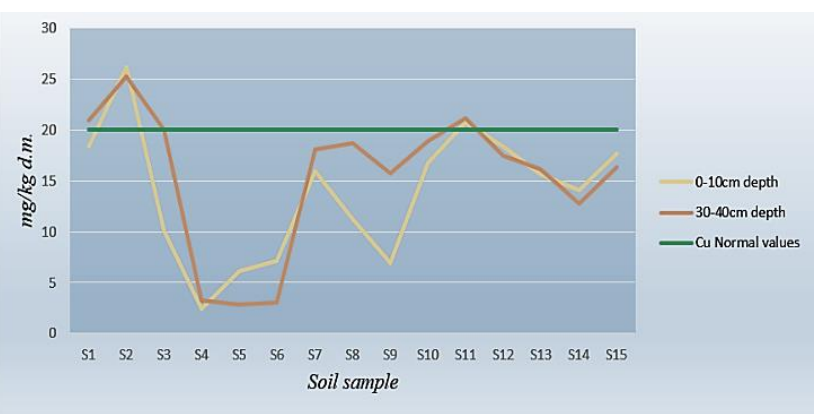

Fig. 7. Variations of $\mathrm{Cu}$ in soil samples

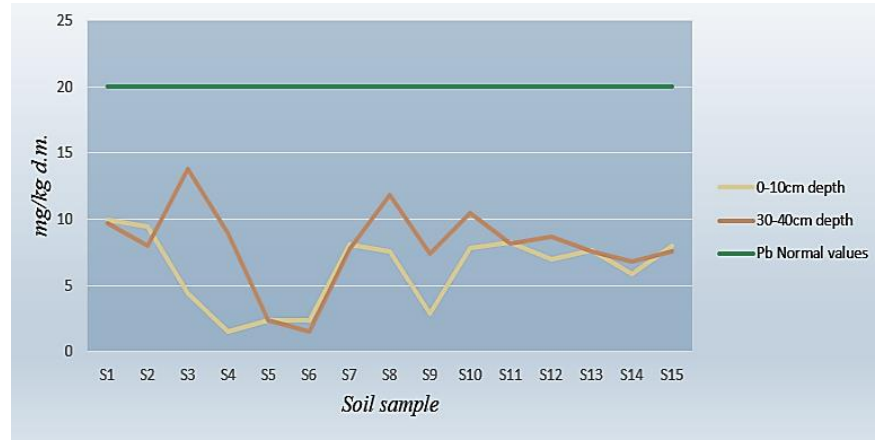

Fig. 8. Variations of $P b$ in soil samples

The comparison of the analytical results with the reference values according to Romanian Order 756/1997 [21] indicated the following aspects:

- for the quality indicators $\mathrm{Mn}, \mathrm{Zn}$, and $\mathrm{Pb}$ the normal values were not exceeded and no exceeding of the Alert Thresholds related to the less sensitive use for any soil sample was registered;

- in the case of the $\mathrm{Cu}$ and $\mathrm{Ni}$ quality indicators, the normal value of $20 \mathrm{mg} / \mathrm{kg}$ was exceeded in few cases;

- the recorded values of "Sulphates" were situated below the alert threshold value;

- "Sulphides and hydrogen sulphide", as well as petroleum products (TPH) concentrations were below the detection limit of the analytical methods applied.

In addition, THP was analyzed in six soil samples, in order to verify that the excavation equipment, considered potential source of pollution, did not bring a contribution in terms of soil quality.

Regarding the $\mathrm{pH}$, the analyzed quality indicator in soil samples was compared with the control sample $\mathrm{pH}$, all $\mathrm{pH}$ values being situated in the neutral range. In addition, the measured values of the iron content, were either comparable or smaller than the iron concentration in blank sample. 


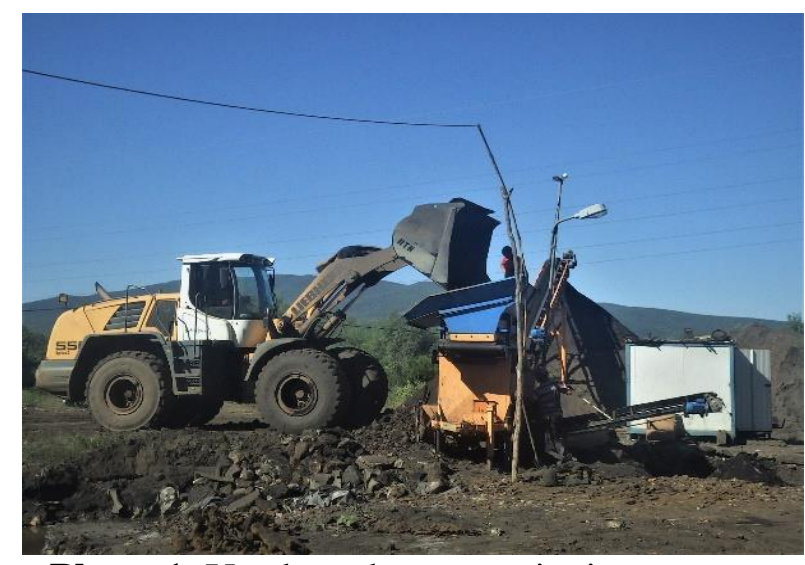

Photo 1. Used sand waste - sieving procees before valorification

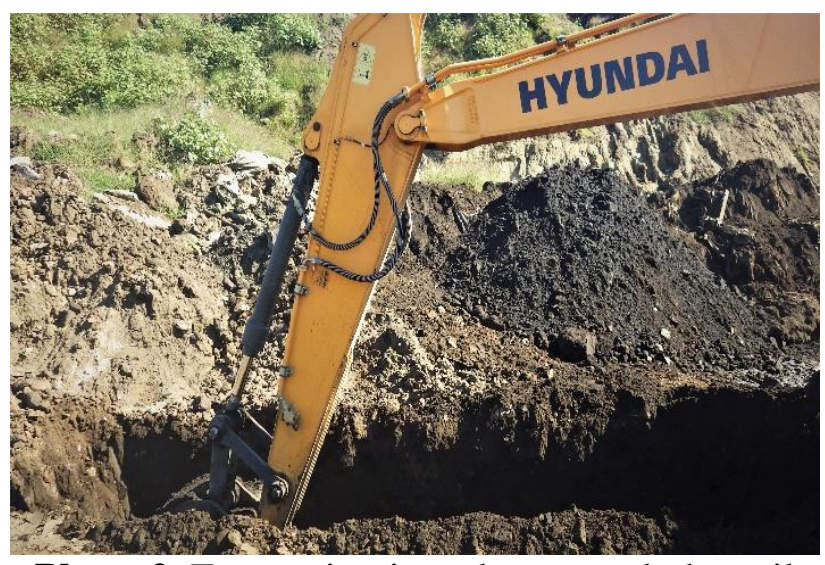

Photo 2. Excavation in order to reach the soil layer underlying the cast iron sand waste

Two photos from the investigated area capture soil sieving (photo 1) and sample collection operations (photo 2).

\section{CONCLUSIONS}

In order to evaluate the soil quality in the area released from the waste, soil samples from 15 points were characterized on two depth layers, the total investigated area being $10600 \mathrm{sqm}$.

The results of the laboratory tests performed indicated that the quality of the soil is not affected, the land investigated being assessed as unpolluted by the activity of waste used sand disposal.

First, the fact that the industrial activity of the waste generator is exclusively focused on the casting of cast iron parts and second, the used sand from cast iron casting molds does not contain pollutants that can affect the soil quality, are signaled as positive aspects.

Application of two measures such as, valorification and storage of sand waste, that work simultaneously, proved to be a beneficial solution in this case, both for the continuation in good conditions of industrial activity, and as a sustainable long-term solution in relation with the environment.

It is important to mention the capitalization of the remaining used sand in deposit, located only at 80 meters from the main activity of casting - cast iron parts, and the steps for arranging a new deposit, according to the requirements of in force environmental legislation is in progress.

\section{REFERENCES}

[1] PRIBUlOVA, A., FUTAS, P., SGEM 2014 Conference Proceeding, 2014, Book 5, vol. 1, p. 121.

[2] JEZIERSKI, J., JANERKA, K., IntechOpen Book, 2011, volume 1, https://doi.org/10.5772/16419.

[3] RAJI, A.,DZIKUNU, P., Book - Scholar's Press, 2014, p. 80.

[4] DAYTON, E.A., WHITACRE, S.D., DUNGAN, R.S., BASTA, N.T., Plant Soil, 2010, 329, no.1-2, p. 27.

[5] MIGUEL, R.E., IPPOLITO, J.A., PORTA, A.A., BANDA NORIEGA, R.B., DUNGAN, R.S., J. Environ. Qual., 2013, 42, no. 2, p. 615.

[6] OMAN, D.E., Hazardous Waste Minimization JAPCA, 1988, 38, no. 7, p. 932.

[7] SATHE, A.J., DESAI, V.M., CHATE, V.R., HOSAMANI, S., Civ. Eng. Environ. Syst., 2015, 7, no. 5 , p. 63.

[8] USEPA, 1992, Metal Casting and Heat Treatment Industry, EPA/625/R-92/009.

[9] USEPA, 1998, EPA Office of Compliance Sector Notebook Project: Profile of the Metal Casting Industry, EPA/310-R-97-004.

[10] USEPA, 2002. Beneficial reuse of foundry sand: A Review of State Practices and Regulation 
[11] ZHANG, H., SU, L., LI, X., ZUO, J., LIU, G., WANG, Y., Front Environ. Sci. Eng., 2014, 8, no.1, p. 89.

[12] BARBARA, S.Q., ROBERT, S., DUNGAN, R.L., CARNIN P., ROSA GALVEZ CATIA, R., DE CARVALHO PINTO, S., Water Air Soil Pollut., 2014, 225, p. 8

[13] SAYEED, J., LOWELL, C.W., Transp. Res. Rec.,1995, 1486, p. 109.

[14] DOGAN-SAGLAMTIMUR, N., Adv. Civ. Eng., 2018, 1927135, p. 1.

[15] SIDDIQUE, R., SINGH, G., Resour. Conserv. Recycl., 2011, 55, no.11, p. 885.

[16] MAVROULIDOU, M., LAWRENCE, D., J. Mater. Cycles Waste Manag., 2019, 21, p. 594.

[17] BALBAY, S., China Foundry, 2018, 16, no.2, p. 141.

[18] BOLD, O.V., MORARU, R.I., GRABARA, J., ASGHER, U., Annales of Hunedoara Engineering - Int. J. Eng. Res., 2015, 2, p. 61.

[19] Stanescu, B. CUCiUREAnU, A., CERniCA, G., CATRINA, G.A., Rom. J. Ecol. Environ. Chem, 2020, 2, no. 2, p. 202.

[20] MUHAMAD, A.A., MOHD JAMIL, M., ISMAIL, Y., IntechOpen Book, 2014, https://doi.org/10.5772/57827.

[21] Order 756/1997 for approval Regulations on environmental pollution assessment with subsequent amendments and completions, http://legislatie.just.ro/Public/DetaliiDocument/13572, [16.06.2021].

Citation: Stanescu, B.A., Cuciureanu, A., Assessment of soil quality in the area of casting parts waste storage specific to cast iron activities, Rom. J. Ecol. Environ. Chem., 2021, 3, no. 1, pp. 79-87. 